This article was downloaded by: [80.1.33.219]

On: 24 September 2013, At: 03:46

Publisher: Routledge

Informa Ltd Registered in England and Wales Registered Number: 1072954 Registered office: Mortimer House, 37-41 Mortimer Street, London W1T 3J H, UK

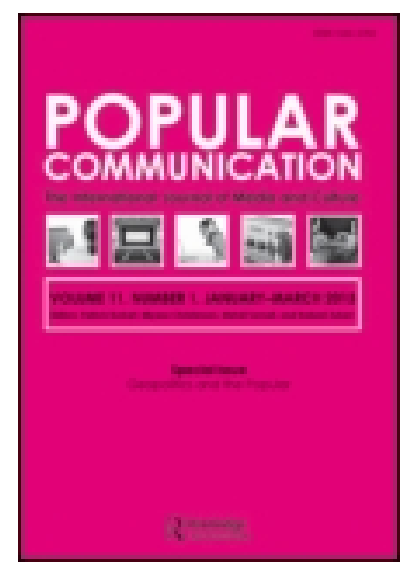

Popular Communication: The International J ournal of Media and Culture

Publication details, including instructions for authors and subscription information:

http:// www.tandfonline.com/loi/ hppc20

\title{
Black Talent and Conglomerate Hollywood: Will Smith, Tyler Perry, and the Continuing Significance of Race
}

\author{
Eithne Quinn ${ }^{\mathrm{a}}$ \\ a University of Manchester \\ Published online: 01 Aug 2013.
}

To cite this article: Eithne Quinn (2013) Black Talent and Conglomerate Hollywood: Will Smith, Tyler Perry, and the Continuing Significance of Race, Popular Communication: The International J ournal of Media and Culture, 11:3, 196-210, DOI: 10.1080/15405702.2013.810070

To link to this article: http:// dx. doi.org/ 10.1080/ 15405702.2013.810070

\section{PLEASE SCROLL DOWN FOR ARTICLE}

Taylor \& Francis makes every effort to ensure the accuracy of all the information (the "Content") contained in the publications on our platform. Taylor \& Francis, our agents, and our licensors make no representations or warranties whatsoever as to the accuracy, completeness, or suitability for any purpose of the Content. Versions of published Taylor $\&$ Francis and Routledge Open articles and Taylor \& Francis and Routledge Open Select articles posted to institutional or subject repositories or any other third-party website are without warranty from Taylor \& Francis of any kind, either expressed or implied, including, but not limited to, warranties of merchantability, fitness for a particular purpose, or noninfringement. Any opinions and views expressed in this article are the opinions and views of the authors, and are not the views of or endorsed by Taylor \& Francis. The accuracy of the Content should not be relied upon and should be independently verified with primary sources of information. Taylor \& Francis shall not be liable for any losses, actions, claims, proceedings, demands, costs, expenses, damages, and other liabilities whatsoever or howsoever caused arising directly or indirectly in connection with, in relation to or arising out of the use of the Content.

This article may be used for research, teaching, and private study purposes. Any substantial or systematic reproduction, redistribution, reselling, loan, sub-licensing, systematic supply, or distribution in any form to anyone is expressly forbidden. Terms \& Conditions of access and use can be found at http://www.tandfonline.com/page/termsand-conditions 
Taylor \& Francis and Routledge Open articles are normally published under a Creative Commons Attribution License http://creativecommons.org/licenses/by/3.0/. However, authors may opt to publish under a Creative Commons Attribution-Non-Commercial License http://creativecommons.org/licenses/by-nc/3.0/ Taylor \& Francis and Routledge Open Select articles are currently published under a license to publish, which is based upon the Creative Commons Attribution-Non-Commercial No-Derivatives License, but allows for text and data mining of work. Authors also have the option of publishing an Open Select article under the Creative Commons Attribution License http:// creativecommons.org/licenses/by/3.0/.

It is essential that you check the license status of any given Open and Open Select article to confirm conditions of access and use. 


\title{
Black Talent and Conglomerate Hollywood: Will Smith, Tyler Perry, and the Continuing Significance of Race
}

\author{
Eithne Quinn \\ University of Manchester
}

\begin{abstract}
This article offers a comparative study of the strategies employed by Will Smith (together with his partner James Lassiter) and Tyler Perry as they surmounted racial barriers to become two of the most successful people in film. What emerges in both cases-despite very different institutional, production, and marketing strategies - is that race has strongly determined the career development of black top talent. Racial hierarchies have presented various obstacles hindering the progress of these individuals, but more surprisingly, such hierarchies have also indirectly facilitated their success. They were seized on by Smith, Lassiter, and Perry as both impetus and opportunity. The final section turns to a consideration of the racial implications of their breaking into film's elite ranks, suggesting that neither the racially incorporative nor resistive dimensions of this achievement have been sufficiently considered.
\end{abstract}

The shift toward more conglomerate domination in the US film industry has led to a widening divide between prestige core film workers and an extensive and precarious peripheral workforce (Christopherson, 2008a, 2008b; Hesmondhalgh, 2013, pp. 83-85, 253-258). Susan Christopherson describes the "strengthening of defensive exclusionary networks to dominate access to the least risky and most lucrative and prestigious end of the industry production spectrum. These networks," she continues, "are composed almost exclusively of white men" (Christopherson, 2008b, p. 89). By and large, then, the white men who always ran the film industry continue to do so, hoarding high-status creative and commercial work as well as the lion's share of profits. In terms of race, the focus of this article, there has been no black or Hispanic major studio chair or head of production, and, as a report headed by media scholar Darnell Hunt (2009) found, promotion opportunities for minorities are directly tied to highly subjective practices of Hollywood's white leaders (see also Galloway, 2006; Krämer, 2012; Nordyke, 2008). As a result, as Los Angeles Times columnist Patrick Goldstein (2011) summarizes, Hollywood is "one of the most minority free industries in America," with "barely any people of color in any high-level positions at any major studio, talent agency or management firm."

Yet given these broad conditions of white opportunity hoarding in the elite ranks of the industry, how can we explain the emergence of African Americans into its top echelons? The two black Americans who have regularly ranked in the Forbes Top 10 lists of Hollywood earners are Will

(C) Eithne Quinn

Correspondence should be addressed to Eithne Quinn, English \& American Studies, University of Manchester, Samuel Alexander Building, Oxford Road, Manchester M13 9PL, United Kingdom. E-mail: eithne.quinn@manchester.ac.uk 
Smith (since the mid-2000s) and Tyler Perry (since the late 2000s). Both have broken significant racial ceilings: Smith became Hollywood's most bankable star by several measures, including the most consecutive films (eight) to gross over $\$ 100$ million in which he had top billing, with many grossing many times that amount (Koehler, 2008). In 2008, Perry became the first black American to own a film studio and, in 2011, the first to top the annual chart of highest earner in the film industry (albeit with earnings from several media), when he made an estimated $\$ 130$ million (Forbes).

While the film texts and public reception of Smith and Perry have received scholarly attention (Brayton, 2011; Harris \& Tassie, 2012; Lyle, 2011; Magill, 2009; Mask, 2012, pp. 155-174; Palmer, 2011; Patterson, 2011; Vera \& Gordon, 2003, pp. 181-184), there remains little consideration of their industry relations. Conducting a literature search, I found no scholarly accounts of Perry's production politics and just two accounts, by Geoff King (2003) and Paul McDonald (2013), of what the latter calls "the business of Will Smith" (pp. 155-177). In these two detailed chapters there remains little if any attention paid to the industry's racial division of labor. McDonald does register the racial importance of Smith's penetrating an otherwise white pantheon of "A-plus list" stars, describing it as "remarkable" (pp. 23, 155), but interprets Smith's blackness as an asset that helps to explain his success without any commensurate discussion of blackness as a liability in a white dominated industry.

This neglect is emblematic of a wider scholarly reticence about tackling what film scholar John Williams describes as the "thorny topic" of commercial black filmmaking in the contemporary period (for exceptions, see Grant, 2004; Lott, 1999; Mask, 2012; Reid, 2005; Watkins, 1998). ${ }^{1}$ This neglect is particularly surprising in light of the history of exclusion of black Americans from film jobs, decision making, and profits (Cripps, 1993; Quinn, 2012; Stewart, 2005), and of Hollywood's continuing notoriety as one of the most racially exclusionary cultural industriesmore so than either television or music (Galloway, 2006; Hunt, 2009). It is perhaps even more surprising because filmic texts have significant power to shape understanding of the world. While this is a widespread assumption driving scholarship on race and film, the racial division of labor behind the scenes that directly feeds into the kinds of stories on screen is rarely examined in detail. This article follows influential work by Robin Means Coleman (2006), Herman Gray (2005), and S. Craig Watkins (1998), who have all identified the pressing need to explore the contested and complex nature of the entertainment industry's racial politics, and to "interrogate the role ... media conglomerates play in shaping and confining Black popular communication's production and circulation" (Means Coleman, 2006, p. 84). A starting proposition of this article, drawing on approaches from cultural industries scholarship (Hesmondhalgh, 2005, 2013), is that the breaking through to the elite ranks of the conglomerated film industry by the likes of Smith and Perry is of discursive and material relevance in racial terms.

Using trade press articles and press interviews, this article offers a comparative study of the different strategies employed by Will Smith (along with his partner James Lassiter) and Tyler Perry as they surmounted racial barriers to become two of the most successful people in film. I organize these strategies into four areas: cross-platform range; commercial imperative; innovative marketing; and self-determination. What emerges is that race has strongly determined the career development of black top talent as they pursued different institutional, production, and marketing strategies. Racial hierarchies have presented various obstacles hindering the progress

\footnotetext{
${ }^{1}$ John Williams, Lane Community College, Oregon, e-mail to author, March, 19, 2013.
} 
of these individuals, but, more surprisingly, I contend that such hierarchies have also indirectly facilitated their success. The racial exclusions of contemporary Hollywood have, ironically, been seized on by Smith, Lassiter, and Perry as both impetus and opportunity. In the final section, I consider the racial implications of their breaking into film's elite ranks, suggesting that neither the racially incorporative nor resistive dimensions of this achievement have been sufficiently considered.

\section{JOINING THE ELITE}

Will Smith and Tyler Perry share common features: both are black American male film stars of the same age (Smith was born in 1968 and Perry in 1969). However, they are rarely discussed together in the popular and trade press for two main reasons. The first is that they occupy very different ground in the contemporary US film industry landscape: Smith makes big-budget Hollywood features whereas Perry makes niche-market independent films. Thomas Schatz has influentially mapped the contemporary film industry, which, since the early 1990s, has been dominated by what he terms "Conglomerate Hollywood": "A new breed of media giants took command of the US film and television industries and became the dominant powers in the rapidly expanding global entertainment industry" (2008, pp. 25-26). With their production company Overbrook Entertainment, Smith and his manager James Lassiter are very much emblems of Conglomerate Hollywood: Smith is a star brand associated with high-production, high-yield films with international reach and Overbrook, founded in 1997, is typical of the star-fronted companies that have sprung up and enjoyed increasing clout as they struck preferential deals with major film companies. Tyler Perry, by contrast, makes films for a domestic black audience, with relatively low production values. Where the average big-budget Hollywood film costs $\$ 100$ million, Perry's budgets range from $\$ 5$ million to $\$ 20$ million. He joint finances, produces, directs, scripts, stars in, and owns his films, all of which have been distributed by Lionsgate, an independent Canadian company. Thus, by remaining fully independent, Perry's films fit more awkwardly into Schatz's schema in which successful independent features tend to be picked up for distribution by the conglomerates' indie subdivisions (2008, pp. 29-31). ${ }^{2}$

The second related reason Smith and Perry are rarely considered together has to do with their divergent black identity politics. Will Smith stars in films with multiracial casts that tend to portray America as "postracial," and in his publicity image he is consistently described as having "transcended race" (see Palmer, 2011). A representative Newsweek cover story declared that Smith's "appeal is so universal that it transcends race" (Smith, 2007). The postracial refrain also pertains to audience: Smith's is huge, racially diverse, and international. By contrast, Perry's cultural products point to continuing de facto racial segregation in the United States in terms of both text and audience. His more recent films do portray some interracial friendships and scenarios and as an actor he has started to branch out into mainstream, multiracial films, but most of the central characters in the films he produces are black and southern. Capturing his narrow but extremely loyal domestic fanbase, Perry explains: "I was able to build and have this amazing career among

\footnotetext{
${ }^{2}$ While Perry has been fully independent in his filmmaking, he has dealt with the majors in the distribution of his television situation comedies, which have screened on TBS, part of Turner Broadcasting, which is a subsidiary of Time Warner.
} 
my own people, but outside of that not a lot of people knew who I was" (CBS, 2010). Despite these conspicuous differences, however, Smith and Perry have more in common than is usually recognized in terms of their industry and production relations. I want to show next that the racial exclusions of Hollywood's creative and commercial leadership heavily determine the experiences of these black producer-performers as they have forged their very different careers.

The first area of comparative ground is cross-platform range: both Smith and Perry first established their entertainment careers outside of film. Indeed it was their capacity to perform in the somewhat less exclusionary realms of TV, music, and theater that helped them overcome film's barriers. Will Smith first achieved fame as a rapper with his radio-friendly group Jazzy Jeff and the Fresh Prince, releasing five albums starting in 1987. With James Lassiter already on board as the group's manager, Smith's first cross-media move was into television, in 1990, when he starred in the sitcom hit Fresh Prince of Bel Air, and then into film, with his first major role in the play adaptation Six Degrees of Separation (Fred Schepisi, 1993). This was followed by a starring role in the action-comedy hit Bad Boys (Michael Bay, 1995) and his blockbuster breakthrough in Independence Day (Roland Emmerich, 1996). The cross-promotional synergy for which Smith is most renowned is the releasing of singles (with heavy video rotation on MTV) and albums to coincide with the theatrical and DVD launch of hit films, aligning release dates to maximize sales (G. King, 2003). Tyler Perry's rise is equally defined by multiple platforms. He started out writing and directing gospel plays, beginning with I Know I've Been Changed, which became a hit in 1998 in Atlanta. After establishing a reputation as a writer, director, and star for the stage, he wrote and produced his 2005 film debut Tyler Perry's Diary of a Mad Black Woman (Darren Grant), which, as a play adaptation, had strong pre-sold attractions and featured his signature character Mabel "Madea" Simmons (the comic black matriarchal granny who Perry plays in drag). Then, in 2006, he published a bestselling Madea book, Don't make a black woman take off her earrings, and launched the first of his TV sitcom/serials House of Payne, which also featured cameo appearances by Madea.

Media scholar David Marshall posits that "whereas the film celebrity plays with aura through the construction of distance, the television celebrity is configured around conceptions of familiarity" (1997, p. 119). Smith, by and large, serves to uphold such an organizing division in his cross-platform trajectory: he first became a household name through television (and music) which he then parlayed into a more "distanced" film career, leaving television behind. Indeed, the star describes his own career development explicitly in terms of using the televisual familiarity of Fresh Prince to aid both filmic and racial crossover. In his early screen role in Six Degrees of Separation, he describes how, as the only nonwhite protagonist, his character "Paul claiming he was Poitier's son made himself feel welcome in a home that he would never otherwise enter, but since TV viewers had already welcomed me into their homes, I could make Paul believable" (quoted in Koehler, 2008). Thus, Overbrook used Smith's televisual ubiquity, from Fresh Prince as well as music television, as a stepping stone to mainstream filmic prestige. By contrast, Tyler Perry, though he established himself in film before TV, did so from the outset using the no-frills intimacy commonly associated with television - thus he serves to complicate Marshall's division. His rapid production schedules and the almost serialized nature of his film releases, averaging two per year, are far removed from the much longer pre-production cycle of major studio filmmaking. Perry has developed a cross-platform brand that draws on the televisual modes of sitcom, soap, and talk-show interview to elicit very strong loyalty from his niche audience which centers on, but is far from limited to, older black women. An oft-repeated strand of Perry's publicity narrative 
is that he was first inspired to start writing by watching a 1991 episode of The Oprah Winfrey Show, in which the host talked about the "healing powers of writing" (Als, 2010). Perry later became a regular guest on the show. Thus, creating utmost "familiarity" with his audience, in his publicity image he constructs himself as, first, a televisual consumer of Oprah, which inspires him to then become a cultural producer. In an Oprah network biography on Perry, he collapses the distance between self and fans: "I am them" (quoted in Walker, 2011). Thus, Overbrook and Perry developed different cross-media strategies, which in both cases helped these versatile black performer-producers to overcome the entry barriers of film.

The second area to consider, as Overbrook and Perry cracked film's elite ranks, is their shared commercial imperative- both in terms of business strategy and publicity image. In interviews, Smith, Lassiter, and Perry insist, to an unusual degree for creative talent, that from early on they were commercially ambitious and focused on self-branding. In a repeated anecdote, Smith says that in 1990 (the year Fresh Prince of Bel Air launched) he already "[wanted] to be the biggest movie star in the world." He and Lassiter found a list of the ten top-grossing films of all time and "said, OK, what are the patterns? We realized that 10 out of 10 had special effects. Nine out of 10 had special effects with creatures. Eight out of 10 had special effects with creatures and a love story" (quoted in Keegan, 2007). Resulting from this bottom-line market analysis, they sought to develop "science fiction films [that] also had other angles going for them" (quoted in Koehler, 2008). Smith's frank commercial imperative is also evident when his rap persona Fresh Prince traveled into the title of his sitcom to maximize exposure and, when Overbrook developed Will Smith singles to market his films, the movie titles-Men in Black (Barry Sonnenfeld, 1997) and Wild Wild West (Barry Sonnenfeld, 1999) — were used as track titles and also became the insistent chorus hooks. Geoff King (2003, p. 64) describes this as a "particularly blatant form of cross-media promotion," encapsulating broader "exercises in cross-platform marketing" that Paul Gilroy has identified, in which music is "relegated to the role of . . mnemonic trigger" (2010, p. 126). Like Smith, Perry included his own name in product titles: his most successful film to date, for instance, which indexes both publicity and screen images, is titled Tyler Perry's Madea Goes to Jail (Tyler Perry, 2009). According to Perry, this was motivated by product differentiation: "I had to have something to set mine apart. So I would make sure my name was on the tickets. ... It's not that I'm narcissistic_I'm very aware of brand building. When you see that name, it gives you a good feeling, like Coke or Disney or Oprah/Harpo" (quoted in Longino, 2008).

From early on, these individuals fashioned their entertainment art very deliberately and "blatantly" in terms of commerce. The self-construction of Smith as king of "Big Willie Weekend"- - the Fourth of July blockbuster-bonanza three-day period in which his star vehicles, for consecutive years, topped the chart-furthers the impression of crass commercialism. Equally, the analogy Perry draws between his own brand and Coke or Disney might seem alienatingly corporatized. Indeed, this helps explain the lack of scholarly interest in, and even contempt for, their extraordinary rise. The Smith and Perry brands seem to exemplify Paul Gilroy's powerful critique of contemporary black Atlantic cultures in Darker Than Blue, which "have acquired high visibility as an adjunct to various commercial processes" (2010, p. 2). In a somewhat similar vein, Leah Aldridge, in a perceptive article that focuses specifically on Will Smith and Tyler Perry's screen images, draws on bell hooks to explore "how blackness is branded and commoditized in our current neoliberal moment," in ways that are "depoliticizing and decontextualizing" (2011, pp. 41, 46). 
Such critiques tend to center on the textual politics and ideological circulation of black commercial culture. But turning the focus toward production politics offers different vantage points, including a consideration of the strong pragmatist tradition in post-civil rights black culture that stresses the turning of play into labor, as historian Robin Kelley (1997, pp. 43-77) has influentially explored. With black America's historic and continuing lack of economic capital partly offset by deep stores of subcultural and performative capital, many African Americans have understood the importance of creative labor as one of the few routes to social mobility. It can be argued that recent black culture has at times been richer socially and aesthetically, in an age of neoliberal inequality, for its self-conscious engagement with its own market relations (Quinn, 2005). Furthermore, with a deep understanding of image management stemming from a history of cultural oppression, post-civil rights African Americans are often particularly adept at developing successful publicity images by narrativizing their own struggles and successes as lifestyle brands: from Oprah (who self-sells the "glamour of misery" [Illouz, 2003]) to the likes of Jay-Z (who endlessly riffs on the hustling reflexivities of his own Roc-A-Fella artistry and commerce). Branding and synergy in the cultural industries are usually invoked to explain the rise of media corporations - the competitive advantage of the scaled-up conglomerate over the hapless independent. Conversely, branding and synergy are also concepts that explain the more unlikely rise of black producer-performers in post-civil rights America-clearly evident in the keen commercial antennae of Overbrook and Tyler Perry. Gilroy is compelling on the need to reinstate the "interpretive significance of slaves having themselves once been commodities," and I would argue that, for better and worse, the synergistic range and vitality of contemporary black self-commoditization springs in part from this legacy (2010, p. 5).

Fueling Overbrook's and Perry's focus on self-branding was a keen racial understanding of the film industry's underresourcing of black productions, which points to the third comparable area traced here-that is, the development of publicity strategies to circumvent industry exclusion. With their move into mainstream filmmaking, Smith and Lassiter encountered Hollywood's set wisdom about the foreign market for black film, which is tersely described by producer Stephanie Allain as "black doesn't travel" (quoted in Galloway, 2006). According to Lassiter, "people don't understand what a struggle it was," facing the line that "African-Americans don't sell around the world" (quoted in Smith, 2007). Overbrook first encountered this industry precept on Bad Boys, which had two black leads (Smith and Martin Lawrence). Frustrated in preproduction that the attitudes of producers, Jerry Bruckheimer and Don Simpson, and of overseas buyers had constrained the raising of production finance, Overbrook embarked on an aggressive international publicity campaign. As Lassiter remarks, "it is a lot of work, but to Will's credit, he is willing to start at zero for each territory" (quoted in Siegel, 2008). Bad Boys, a film with very low expectations outside the United States, exceeded its domestic box office in foreign grosses. Their prior hip-hop careers helped equip Overbrook with insights to challenge conventional wisdom. Jazzy Jeff and the Fresh Prince had recorded their first album in London, and Lassiter explains: "You go to the territories, and you see a direct response to the sales of the records by being in the territory. We were told that it didn't apply to movies. We didn't believe it" (quoted in Siegel).

The point to emphasize is that the initial barrier thrown up by the industry to big-budget films with black leads motivated Smith and Lassiter to cultivate and cater to the international market. Just at the moment when overseas was becoming so central to Conglomerate Hollywood, Overbrook was already attuned to capitalizing on these markets because of the testing experience of overcoming racial exclusion. Many of Smith's more recent vehicles have focused on 
particular countries, notably China, the fastest growing theatrical market, and Overbrook has also been aggressive in its pursuit of foreign investment-another key trend of the conglomerates. The release of blockbuster smash Hancock (Peter Berg, 2008) coincided with the Beijing Olympics, and Overbrook's Karate Kid (Harald Zwart, 2010), starring Will Smith's son Jaden, was filmed in China and co-funded by China Film Group, the government-run film company. As Amy Pascal chair of Columbia Pictures remarks, Overbrook "caught on" to the commercial need for global stories "before a lot of other people did" (quoted in Smith, 2007). It seems clear that Overbrook's early crossover cultivation of the suburbs, with Smith being welcomed into people's homes because of Fresh Prince, provided the model for developing a transnational fanbase.

At first glance it might seem that Perry has little in common in marketing terms with Overbrook, given his narrower domestic audience. However, like Overbrook, he developed models to circumvent the lack of investment by the majors and applied marketing insights to film that he developed in other media. He had first looked to Hollywood for finance to turn one of his plays into a film but had received a "lukewarm" response: "middle-aged, churchgoing black women . . . didn't go to the cinema" and "the melodramatic script . . . would need major changes" (Garratt, 2010). Hollywood's snub and neglect of the black female audience forced Perry to consider less conventional deals, which in turn suited him (and his core audience) far better. Even more so than Overbrook, the barriers erected had unintended benefits. Rebuffed by Hollywood, Perry put up his own money and struck an unorthodox deal with Lionsgate, which allowed him to retain final cut and ownership of his products.

Perry's independent strategy was aided by notable grassroots publicity techniques. As he took his plays across the southern black theater circuit, he developed a mailing list which reportedly grew to more than a million names (Garratt, 2010). So, when he released his first feature film, he informed fans by email. Diary of a Mad Black Woman ultimately made about $\$ 65$ million, from a production budget of just $\$ 5.5$ million. Perry has continued to release regular film installments that can open fairly big without proportionate advertising costs. Rather than the expensive market research practices conventionally used in selling major films, such as previewing, market analysis, focus groups, and surveys (Drake, 2008), Perry instead tracks responses through his free emailing list and through stage plays, for which he himself gets paid. He says, "I've been going on tour for years and am doing my research in those moments" (quoted in Albiniak, 2011). Thus, both Overbrook and Perry developed reactive marketing strategies and tailored their product to cultivate their disparate audiences, variously overcoming, outperforming, and undercutting Conglomerate Hollywood norms.

The first three comparable areas have all pointed to how Overbrook and Perry used their creative resources to leverage power and profits within an exclusionary industry, which leads to my final area of economic and creative self-determination. As top-end freelance workers, stars have gained more control over their career development in the poststudio era and have won a far greater share of profits (Hesmondhalgh, 2005; McDonald, 2013, pp. 41-64). While this is true for A-list stars generally, it has particular relevance for those from minority groups who have historically been locked out of profits and had limited power over the development of their own screen images. In terms of profits, starting with Eddie Murphy's production company and his deal with Paramount to make the Beverly Hills Cop series, some black stars began to reap sustained high earnings. Developing this trend, Overbrook expertly brokered deals that included high frontend salaries and back-end percentages of box office receipts. Smith's estimated earnings (before 
managers, agents, etc., have taken their cuts) averaged \$41 million per year between 2005 and 2009. ${ }^{3}$ Lassiter, who also got paid in his own right as producer on many Overbrook productions, has emerged as a master hip-hop-era negotiator, overseeing the brokering of preferential deals.

For all the exorbitant pay and gross deals enjoyed by the Overbrook partners, they nonetheless by and large remained financially dependent on their employers and investors. Along with greatly enriching themselves, Smith and Lassiter have lined the conglomerate coffers, especially of Columbia/Sony. Overbrook's relationship with Japanese-owned Columbia is of long duration, starting in 1995 and with an ongoing first-look deal first signed in 2001. By contrast, Tyler Perry, who puts up half the production costs of his films and gets to keep roughly half the profits and the masters, has been rewarded for remaining independent: average estimated earnings of an astronomical \$112 million per year between 2008 and 2012. ${ }^{4}$ The racial motivation underpinning Perry's economic self-determination is hard to overstate. The black drive for wealth creationfrom a community so long locked out of entrepreneurial prospects in the "land of opportunity" due to racism (Oliver \& Shapiro, 1997) — has powerfully traveled into black film culture (Watkins, 1998; Quinn, 2010). In Perry's extraordinary case, his studio facility contains an underground vault holding all his masters which, according to Ebony, embodies "the core of Perry's business philosophy and, thus, his wealth: ownership" (Johnson, 2011, p. 85). Invoking the historic lack of entrepreneurial opportunity in black America, Perry describes his construction-worker father's story, building houses for a developer and receiving only a weekly "pay check": "I'm not interested in working as hard as my father did - and I absolutely have his work ethic - for nothing. I'm going to be the man who owns the house" (quoted in Johnson, p. 85).

The increased clout of top talent in the contemporary industry not only gives rise to vast earnings but also to more creative control. Lassiter, Smith, and their agent Ken Stovitz, who has worked with them for more than 20 years and became an Overbrook co-partner in 2008, have been able to build the Smith and Overbrook brands, finding their own scripts and directors and coming up with packages. As a result, in his monograph on contemporary Hollywood stardom, McDonald states that "what is maybe most interesting about Smith is how he illustrates star agency in the system" (2013, p. 176). Perry has even more control over his product, remarking of his distributor's hands-off approach: "Lionsgate has been incredibly affirming of my relationship with my audience-I've always had the artistic freedom to speak what I want, how I want, and when I want through my films" (quoted in "Lionsgate extends," 2011).

Repeatedly, race was both impediment and impetus to the career development of the Overbrook partners and Perry. This is not to make a racially essentialist argument; indeed their activities can find correlatives in the career development of non-black top talent. For instance, Smith's aggressive international publicity campaigns rival those of his friend Tom Cruise. Perry's self-financing and marketing through the churches may bring to mind the independent Christian filmmaking of Mel Gibson's The Passion of the Christ (2004). Perry's dexterous above-the-line multi-tasking (scripting, directing, acting, and so forth) is similar to Woody Allen. Nonetheless, to a striking extent, Overbrook and Perry exemplify wider black trends in the contemporary cultural

\footnotetext{
${ }^{3}$ In the Forbes yearly lists of “The World's Most Powerful Celebrities," sorted by "pay," Smith ranked eighth highest in the film business in 2005 (\$24 million), seventh in 2006 (\$25 million), ninth in 2007 (\$31 million), fourth in 2008 (\$80 million), seventh in 2009 (\$45 million), ninth in 2011 (\$36 million), and thirteenth in 2012 (\$30 million).

${ }^{4}$ Perry emerged on the Forbes "World's Most Powerful Celebrities" list in 2008 when, sorted by "pay," he ranked third highest film celebrity (\$125 million), fourth in 2009 (\$75 million), second in 2010 (\$125 million), first in 2011 (\$130 million), and sixth in 2012 (\$105 million).
} 
industries. Many black musicians, notably Ice Cube (O'Shea Jackson), Queen Latifah (Dana Owens), and Master P (Percy Miller), have used their music careers as entrée into film, establishing successful movie production companies. Perry and Smith/Lassiter are among a number of celebrated black self-made entertainment entities or "moguls," such as Oprah Winfrey, Sean (P-Diddy) Combs, and Curtis (50 Cent) Jackson, who produce and perform and are masters of synergy. In the film industry, a key point of comparison is performer-producer Spike Lee who is known for savvy marketing and formidable range as writer, director, and actor. Like Perry and Overbrook, Lee has foregrounded the commercial dimensions of his art, most controversially through the series of Air Jordan TV advertisements he made for Nike starting in the late 1980s (see Gilroy, 1993, p. 189).

Though by no means the exclusive province of blackness, the areas I have mapped are common repertoires in contemporary black cultural production. To stress how these stars have used race as an opportunity is not to downplay the continuing racial obstacles they face, even at the elite end of the industry. This section has foregrounded obstacles but also suggested ways in which racial difference, racial insight, and even racial barriers have emerged as impetus and opportunity. Race is an impetus because the historic and continuing experience of racism in America acts as a complex resource and spur, priming these creative individuals to surmount Hollywood's possessive investment in whiteness (Lipsitz, 1998). Behind the comic and affable screen personas of both Smith and Perry is a frankly acknowledged steely ambition and business awareness that they share with Lassiter, which is partly racially determined. Race is an opportunity because Conglomerate Hollywood, though its growth since the 1980s seems overwhelming, is not all-absorbing or monolithically efficient-its racist assumptions present some opportunities for minority cultural producers. Indeed, when such corporate fault-lines are combined with the rich performative and subcultural resources of black America in an increasingly synergistic, celebrity-fronted industry environment, the opportunities presented can be substantial.

\section{RACIAL IMPLICATIONS OF JOINING THE ELITE}

I have been arguing that these stars are worthy of attention by media and race scholars and that we should not underestimate the continuing role of race in their industry relations. But the question arises: in what ways and to what extent does the success of Overbrook and Perry matter in racial terms, beyond their own individual achievements in diversifying a prominent lily-white industry? With the vast material inequalities of contemporary America that are strongly determined by race (King \& Smith, 2011; Winant, 2001, pp. 147-176) and that are legitimated by celebrity culture (Hesmondhalgh, 2005), to what extent, if any, might the elite success of these performer-producers work to counter persisting racial injustice in the film industry and beyond? What follows is a brief account of how they have perceived and responded to the industry's race politics, and some very brief remarks about how this might feed into their all-important textual outputs.

The first point to make is that the emergence of Overbrook and Tyler Perry has increased black employment in film. Black top talent, just like nonblack talent, develops informal networks, but these tend to be much more diverse than their white counterparts. For all the "sincere fictions" of liberal Hollywood-harboring the belief that whites are doing the most to help integrate the industry - the best way to diversify is to have more people from underrepresented groups in 
decision-making positions (Quinn, 2011). While both Smith and Perry have key white executives in their core networks, such as Overbrook's in-house agent Ovitz and Tyler Perry's studio production head Ozzie Areu, their companies remain much more diverse than is standard. Given that there are hardly any minorities at Hollywood's key management firms, Lassiter himself, as Smith's longtime production company chief, represents diversification. When journalist Patrick Goldstein (2011) "asked a couple of reporter pals to name the most powerful black executive in town, a lot of head-scratching ensued before we decided that the person with the most clout was probably James Lassiter." Smith's black wife Jada Pinkett Smith is also an Overbrook producer and director. Perry's attorney, Matthew Johnson, is an African American partner in the leading firm Ziffren Brittenham - one of the few prominent black lawyers in Hollywood. As an indication of their broader networks, Overbrook Entertainment and Perry's 34th Street Films have each produced films written and/or directed by black women. Although, as Saha (2012) has shown, more behind-the-scenes participation from a given minority group does not necessarily translate into fuller depictions of that group on screen, it is a start.

Almost by default, black top talent generates more black jobs. But this is where the similarities end because Overbrook and Perry paint different pictures of the industry's racial status quo. Smith and Lassiter have spoken out about racial barriers in Hollywood that affect them individually, as in the budget and casting of particular films. This happened pointedly during the development of the romantic comedy Hitch (Andy Tennant, 2005). Columbia executives did not want to cast a black actress to play alongside Smith in case it was seen as a "black film," leading Lassiter to criticize Hollywood's assumption that "African Americans can't have successful romantic comedies" (quoted in Smith, 2007; see Onwuachi-Willig, 2007). However, Smith and Lassiter have had very little to say about the endemic racial exclusions that affect less elite minority workers. In fact, perhaps fuelled by his own overwhelming sense of liberal-individualist achievement, Smith tends to stress opportunities rather than barriers: "For black actors, when you hit that tipping point and you've made it, your position is locked forever. You know Sam Jackson, Eddie Murphy, Denzel Washington, Martin Lawrence, Halle Berry-we can go on making movies as long as we want. It's the white actors that come and go" (quoted in Stein, 2006). By adding the quip about white disadvantage, Smith risks trivializing the continuing poor prospects of many minority workers in the industry.

Perry, by contrast, tends to act as a spokesperson and advocate for black industry workers. In press statements, he acknowledges that his own uplift narrative can militate against recognition of continuing racism: he "cautions his story of success is a bit untraditional," stating that "there are more African Americans who are unemployed in Hollywood than any other group of people, more actors struggling, more writers struggling" (quoted in "Tyler Perry," 2010). Perry publicly supports black organizations such as the National Association for the Advancement of Colored People (NAACP) and Al Sharpton's National Action Network, which lobby on behalf of blacks for jobs and representation in entertainment. He made the biggest ever individual donation ( $\$ 1$ million) to the NAACP, insisting the organization is "just as important now as it was 100 years ago" (quoted in "Tyler Perry"). Such statements run counter to the more usual view that such organizations are of declining significance in the age of "color-blindness" (see Brown, Carnoy, Currie, \& Duster, 2003; Winant, 2001, 147-176).

Perry may have gone further than any other individual in generating black jobs in film when he opened Tyler Perry Studios in 2008. It is one of the largest independently owned studios outside of Hollywood, with five soundstages and a large back lot, and when the facility is in 
full production, making two TV shows and a feature film, estimates of workers onsite range from 300 to 400 (Johnson, 2011, p. 83). Perry certainly emphasizes the studio's racial significance in terms of jobs: "To have that many Black people working in this business looking at each other and seeing themselves ... especially the ones who come from Hollywood. They say: 'I've been on sets for years, and I was the only Black face there.' To come here and see this-it's all love" (quoted in Johnson, p. 83). Job creation is a strong plank of Perry's publicity image, with TV host Kathie Lee Gifford (NBC, 2012) describing him as having "put half the state to work in Atlanta." When asked what money means to him, Perry states: "It means that I can pay a lot of people to keep working" (CBS, 2012). It is of course important not to idealize the studio's multi-racial working environment. Indeed the Writers Guild held protests in 2008 at the studio, accusing Perry of firing four staff writers in retaliation for their efforts toward organizing union representation - this dispute was finally settled in 2011 when his writers joined the guild (McNary, 2011). In light of Perry's own exorbitant earnings, it is lamentable that, as an employer, he might resist labor organization and decent wages. Work at Tyler Perry Studios for many is no doubt as testing, exploitative, and perhaps precarious as in other areas of today's cultural industries (Hesmondhalgh, 2013, pp. 253-258). Yet even if some of the criteria for "bad work" in the cultural industries (Hesmondhalgh \& Baker, 2011, pp. 25-51) exist at Tyler Perry Studios, when one considers that it is located in a predominantly working-class area of southwest Atlanta on a site previously owned by Delta Airlines that had been empty for more than a decade, the bleak alternative employment prospects in deindustrialized America are indexed. Though a stark and troubling gap exists between Perry's own remuneration and that of his workers, and while his riches have been greatly augmented by the tax breaks and incentives enjoyed by media producers in states like Georgia, his many statements about the importance of black job generation in the cultural industries are far from wholly disingenuous.

The different racial outlooks of Overbrook and Perry in industry terms travel into the textual meanings of their film products. As scholars have argued, hugely successful Will Smith vehicles such as Pursuit of Happyness (Gabriele Muccino, 2006), I am Legend (Francis Lawrence, 2007), and Hancock depict worlds that are largely postracial in which there is little sense of racial hierarchy. While some scholars persuasively suggest that veiled racial critiques circulate in particular Smith films (see Brayton, 2011; Palmer, 2011), there is a general, and generally convincing, view that Smith's star image of professionalism under duress, transcendence and sacrifice, and acculturated black charisma, by and large, serve to disavow continuing, entrenched racial injustice in America (Aldridge, 2011; Vera \& Gordon, 2003, pp. 181-184). I would suggest that both the undertones of racial critique and the dominant note of postracialism are spurred by the vision of America and Hollywood that Overbrook projects. Capturing the confluence of production and text, Lassiter describes "looking at our properties from development through production through marketing as global movies. That's what we do with Will, and that's what we like for our company to represent" (quoted in Cohen, 2008). In conjuring a sense of the international free trade of ideas and resources, Overbrook and "Will Smith" tell at best partial stories-Smith vehicles are not really "global movies" so much as pro-American ones with great international reach. Nonetheless, such films are consistent with these black producers' own individual epic business narratives and have assuredly enhanced certain kinds of racial tolerance (with Smith attaining, in the words of one industry executive, "a Tom Hanksian level of likability" [quoted in Smith, 2007]). 
There has been substantial scholarly criticism of the representational politics of Perry's films, focusing on the gendered representations in his marriage-bound plots (Lyle, 2011; Patterson, 2011), his uppity black middle-class antagonists (Harris \& Tassie, 2012), and his controversial keynote portrayal of Madea (Aldridge, 2011; Mask, 2012, pp. 155-174). I would simply point out that production context might, again, offer new ways of slicing into textual themes. It enables a shift from heavily analyzed "politics of recognition" thematic terrain toward "politics of redistribution" (Fraser, 1997). Black unemployment, working poverty, homelessness, and indebtedness are recurrent narrative elements, particularly in Perry's films since the start of the financial crisis. The melodramatic resolutions involve black kinship networks overcoming material (and spiritual) adversity that cross class lines in ways that move beyond the customary bifurcation of ghetto versus gentrified in many Hollywood genre films. Taking a representative example, Tyler Perry's Madea's Witness Protection (2012) is a comedy-melodrama about a disgraced white Wall Street financier who hides out in Madea's house in black Atlanta. It certainly misses opportunities to critique investment banking malfeasance; but it nonetheless ends with a joyous "mortgage burning ceremony," set in the tiny black church in Madea's neighborhood, following the retrieval of its hard-earned money from the clutches of the bank's Ponzi scheme. The church celebrates finally paying off the loan that had long threatened its existence. Madea's uplift homilies and grassroots redistributive tactics, which are repeatedly depicted in Perry's oeuvre, must be considered in relation to a production context of black wealth and job creation-of some actual black economic uplift through cultural labor in the same southwest Atlanta area where Madea lives, far away from the corporate concentrations and exclusions of Hollywood. Though far from anti-capitalist, such politics-of-redistribution themes surely amount to something more than "neoliberal 'boot strap' rhetoric concealed in emotionality" (Aldridge, 2011, p. 45).

\section{CONCLUSION}

Overbrook and Tyler Perry have developed different strategies in relation to Schatz's "new breed of media giants": one wresting significant control within the system and the other resisting the pull of the conglomerate vortex. Will Smith and James Lassiter greatly enriched Columbia and the other majors in financial and symbolic terms. In their business practice and on screen, they have showcased the potential for racial advances within neoliberalism. In doing so, they, perhaps unavoidably, help to legitimate that system which is built on profound inequalities. Nonetheless Smith and Lassiter did become very active black agents, confronting some of the industry's racist precepts, and, at their best, Will Smith vehicles subtly engage these racial politics. By skillfully developing their conglomerate- and audience-facing brands, they showed themselves to be highly adept and focused brokers of symbolic and commercial capital. They hustled the corporations with a deep hip-hop-inflected awareness of the conglomerates' great dependency on top creatives to reduce financial risk. This enabled Overbrook, despite racial barriers, to negotiate as much self-determination as any star-fronted company in Conglomerate Hollywood-this feat should not be underestimated.

Tyler Perry has done something even more remarkable and, in my view, with less political cost. Film scholars, as of 2013, describe Lionsgate as "the last indie standing" (Perren, 2013), and this is in no small part thanks to Perry. He has taken on the risks that are normally absorbed by the conglomerates and their private investors and, as a result (after a spell of homelessness!), he has 
reaped the rewards. He pays for an infrastructure, owning his own studio, which opens important questions about what it means to be a socially responsible black cultural industry employerquestions he has insufficiently answered. Perry has managed to join the elite by replicating some of the strategies of the majors while working outside of their structural determinations, establishing a seditiously remunerative independent business model, which others might replicate. $\mathrm{He}$ has not enriched the major film companies, nor, I would suggest, have his black female-centered melodramas served to legitimate corporate interests. Perry's racial experiences and attitudes have spurred him to forge and maintain his own preferential independent course. In this, he shares a good deal with his corporate-friendly and supposedly post-racial peers, Smith and Lassiter. All three have reached the very top, against the racial odds but also ironically because of their hard-won experience of those racial odds.

\section{REFERENCES}

Albiniak, P. (2011, November 11). Perry's bet on himself pays off handsomely. Daily Variety. Retrieved from http:// global.factiva.com/

Aldridge, L. (2011). Mythology and affect: The brands of cinematic blackness of Will Smith and Tyler Perry. Spectator: The University of Southern California Journal of Film and Television, 31(1), 41-47.

Als, H. (2010, April 26). Mama's gun: The world of Tyler Perry. New Yorker. Retrieved from http://global.factiva.com/

Brayton, S. (2011). The racial politics of disaster and dystopia in I am legend. Velvet Light Trap, 67, 66-76.

Brown, M. K., Carnoy, M., Currie, E., \& Duster, T. (2003). White-washing race: The myth of a color-blind society. Berkeley, CA: University of California Press.

CBS. (2010, July 25). The narrative, growing body parts, Tyler Perry. CBS News. Retrieved from http://global. factiva.com/

CBS. (2012, June 27). Interview with Tyler Perry. CBS This Morning. Retrieved from http://global.factiva.com/

Christopherson, S. (2008a). Labor: The effects of media concentration on the film and television workforce. In P. McDonald \& J. Wasko (Eds.), The contemporary Hollywood film industry (pp. 155-166). New York, NY: Wiley-Blackwell.

Christopherson, S. (2008b). Beyond the self-expressive creative worker: An industry perspective on entertainment media. Theory, Culture and Society, 25(7-8), 73-95.

Cripps, T. (1993). Making movies black: The Hollywood message movie from World War II to the Civil Rights era. New York, NY: Oxford University Press.

Cohen, D. (2008, December 12). James Lassiter: All business, no limelight. Daily Variety. Retrieved from http://global. factiva.com/

Drake, P. (2008). Distribution and marketing in contemporary Hollywood. In P. McDonald \& J. Wasko (Eds.), The contemporary Hollywood film industry (pp. 63-82). New York, NY: Wiley-Blackwell.

Forbes. (2005-2012). The world's most powerful celebrities. Retrieved from http://www.forbes.com/celebrities/

Fraser, N. (1997). Justice interruptus. London, United Kingdom: Routledge.

Galloway, S. (2006, February 24). Game plan. Hollywood Reporter. Retrieved from http://global.factiva.com/

Garratt, S. (2010, August 21). Hollywood blackbuster; Tyler Perry built a multi-million-dollar film and television empire from scratch. Telegraph Magazine. Retrieved from http://global.factiva.com/

Gilroy, P. (1993). Small acts. London, United Kingdom: Serpent's Tail.

Gilroy, P. (2010). Darker than blue: On the moral economies of black Atlantic culture. Cambridge, MA: Harvard University Press.

Grant, W. (2004). Post-soul black cinema. New York, NY: Routledge.

Goldstein, P. (2011, January 27). Oscar nominations an all-white affair. Los Angeles Times. Retrieved from http://global. factiva.com/

Gray, H. (2005). Cultural moves: African Americans and the politics of representation. Berkeley, CA: University of California Press.

Harris, C., \& Tassie, K. (2012). The cinematic incarnation of Frazier's black bourgeoisie: Tyler Perry's black middle class. Journal of African American Studies, 16(2), 321-344. 
Hesmondhalgh, D. (2013). The cultural industries (3rd ed.). London, United Kingdom: Sage.

Hesmondhalgh, D., \& Baker, S. (2011). Creative labour: Media work in three cultural industries. London, United Kingdom: Routledge.

Hesmondhalgh, D. (2005). Producing celebrity. In J. Evans \& D. Hesmondhalgh (Eds.), Understanding media: Inside celebrity (pp. 97-134). Maidenhead, United Kingdom: Open University Press.

Hunt, D. (2009). Rewriting an all-too-familiar story? The 2009 Hollywood Writers report. Los Angeles, CA: Writers Guild of America West. Retrieved from http://www.wga.org/uploadedFiles/who_we_are/

Illouz, E. (2003). Oprah Winfrey and the glamour of misery. New York, NY: Columbia University Press.

Johnson, R. (2011, August). His own man. Ebony, 80-85.

Keegan, R. (2007, November 29). The legend of Will Smith. Time Magazine. Retrieved from http://www.time.com/time/ magazine/article/

Kelley, R. (1997). Yo' mama's disfunktional! Fighting the culture wars in urban America. Boston, MA: Beacon.

King, D., \& Smith, R. (2011). Still a house divided: Race and politics in Obama's America. Princeton, NJ: Princeton University Press.

King, G. (2003). Stardom in the Willennium. In T. Austin \& M. Barker (Eds.), Contemporary Hollywood stardom (pp. 62-73). Abingdon, United Kingdom: Hodder Arnold.

Koehler, R. (2008, December 12). Smith pushes his range as an actor. Daily Variety. Retrieved from http://global.factiva. $\mathrm{com} /$

Krämer, P. (2012). "Black is in": Race and genre in early 1990s American cinema. Iluminace, 24(3), 13-29.

Lipsitz, G. (1998). The possessive investment in whiteness: How white people profit from identity politics. Philadelphia, PA: Temple University Press.

Lionsgate extends partnership with Tyler Perry with new multiyear deal. (2011, April 15). Entertainment Weekly. Retrieved from http://global.factiva.com/

Longino, B. (2008, March 6). Movie talk. Atlanta Journal-Constitution. Retrieved from http://global.factiva.com/

Lott, T. (1999). The invention of race: Black culture and the politics of representation (pp. 139-151). Malden, MA: Blackwell.

Lyle, T. (2011). "Check with yo' man first; check with yo' man": Tyler Perry appropriates drag as a tool to recirculate patriarchal ideology. Callaloo, 34(3), 943-958.

Magill, D. (2009). Celebrity culture and racial masculinities: The case of Will Smith. In E. Watson (Ed.), Pimps, wimps, studs, thugs and gentlemen: Essays on media images of masculinity (pp. 126-140). Jefferson, NC: McFarland.

Marshall, P. D. (1997). Celebrity and power: Fame in contemporary culture. Minneapolis, MN: University of Minnesota Press.

Mask, M. (Ed.). (2012). Contemporary black American cinema: Race, gender and sexuality at the movies. New York, NY: Routledge.

McDonald, P. (2013). Hollywood stardom. Oxford, United Kingdom: Wiley-Blackwell.

McDonald, P., \& Wasko, J. (Eds.). (2008). The contemporary Hollywood film industry. Malden, MA: Blackwell.

McNary, D. (2011, December 6). Perry pacts for "Payne" scribes. Daily Variety. Retrieved from http://global.factiva.com/

Means Coleman, R. (2006). The gentrification of 'black' in black popular communication in the new millennium. Popular Communication, 4(2), 79-94.

Moody, N. M. (2011, October 20). Tyler Perry honored by Al Sharpton group. Associated Press Newswires. Retrieved from http://global.factiva.com/

NBC. (2012, June 29). Interview: Eugene Levy discusses his new movie: "Tyler Perry's Madea's witness protection." NBC News Today. Retrieved from http://global.factiva.com/

Nordyke, K. (2008, December 19). NAACP: Biz short on diversity again, Hollywood Reporter. Retrieved from http:// global.factiva.com/

Oliver, M., \& Shapiro, T. (1997). Black wealth/white wealth: A new perspective on racial inequality. New York, NY: Routledge.

Onwuachi-Willig, A. (2007). There's just one hitch, Will Smith: Examining title VII, race, and casting discrimination on the fortieth anniversary of Loving v. Virginia. Wisconsin Law Review, 319-343.

Palmer, L. (2011). Black man/white machine: Will Smith crosses over. Velvet Light Trap, 67, 28-40.

Patterson, R. (2011). "Woman thou art bound": Critical spectatorship, black masculine gazes, and gender problems in Tyler Perry's movies. Black Camera, 3(1), 9-30. 
Perren, A. (2013). Last indie standing: The special case of Lions Gate in the new millennium. In G. King, C. Molloy, \& Y. Tzioumakis (Eds.), American independent cinema: Indie, Indiewood, and beyond (pp. 108-120). London, United Kingdom: Routledge.

Perry, T. (2006). Don't make a black woman take off her earrings: Madea's uninhibited commentaries on love and life. New York, NY: Riverhead.

Quinn, E. (2012). Closing doors: Hollywood, affirmative action, and the revitalization of conservative racial politics. Journal of American History, 99(2), 466-491.

Quinn, E. (2011). Sincere fictions: The production cultures of whiteness in late 1960s Hollywood. Velvet Light Trap, 67, 3-13.

Quinn, E. (2010). "Tryin' to get over": Super fly, black politics, and post-civil rights film enterprise. Cinema Journal, $49(2), 86-105$.

Quinn, E. (2005). Nuthin' but a G thang: The culture and commerce of gangsta rap. New York, NY: Columbia University Press.

Reid, M. (2005). Black lenses, black voices: African American film now. Lanham, MD: Rowman and Littlefield.

Saha, A. (2012). "Beards, scarves, halal meat, terrorists, forced marriage": Television industries and the production of "race." Media, Culture \& Society, 34(4), 424-438.

Schatz, T. (2008). The studio system and conglomerate Hollywood. In P. McDonald \& J. Wasko (Eds.), Contemporary Hollywood film industry (pp. 13-42). Malden, MA: Blackwell.

Siegel, T. (2008, December 12). Smith, Lassiter bent on world conquest. Variety. Retrieved from http://global.factiva. com/

Smith, S. (2007, April 9). The \$4 billion man-Will Smith. Newsweek. Retrieved from http://global.factiva.com/

Stein, R. (2006). Following his bliss Will Smith looks inward. San Francisco Chronicle. Retrieved from http://www. sfgate.com/entertainment/article/

Stewart, J. (2005). Migrating to the movies: Cinema and black urban modernity. Berkeley, CA: University of California Press.

Tyler Perry: Playing by his own rules. (2010, April 1). The Crisis. Retrieved from http://global.factiva.com/

Vera, H., \& Gordon, A. (2003). Screen saviors: Hollywood's fictions of whiteness. Lanham, MD: Rowman and Littlefield.

Walker, D. (2011, October 16). "Humor saved my life"; Tyler Perry offers glimpses of his life story in a new Oprah network biography. The Times-Picayune. Retrieved from http://global.factiva.com/

Watkins, S. C. (1998). Representing: Hip hop culture and the production of Black cinema. Chicago, IL: Chicago University Press.

Winant, H. (2001). The world is a ghetto: Race and democracy since World War II. New York, NY: Basic Books. 